\title{
Belphégor
}

\section{The emergence of the middlebrow novel in the Netherlands: the 'New Novels' Series of World Library}

\section{Erica van Boven}

\section{OpenEdition}

Journals

Electronic version

URL: http://journals.openedition.org/belphegor/973

DOI: 10.4000/belphegor.973

ISSN: 1499-7185

Publisher

LPCM

\section{Electronic reference}

Erica van Boven, « The emergence of the middlebrow novel in the Netherlands: the 'New Novels' Series of World Library », Belphégor [Online], 15-2 | 2017, Online since 21 November 2017, connection on 02 May 2019. URL : http://journals.openedition.org/belphegor/973 ; DOI : 10.4000/belphegor.973

This text was automatically generated on 2 May 2019.

\section{(c)}

Belphégor est mis à disposition selon les termes de la Licence Creative Commons Attribution - Pas d'Utilisation Commerciale - Pas de Modification 4.0 International. 


\title{
The emergence of the middlebrow novel in the Netherlands: the 'New Novels' Series of World Library
}

\author{
Erica van Boven
}

\section{Introduction}

1 Most scholars agree that middlebrow should be placed in the time period after World War I. Indeed, in the $1920 \mathrm{~s}$ and 1930s, at the time of the increasing democratization, commercialization and expansion of the book market, when modernism achieved its high status, middlebrow culture became apparent as a third category between the popular and the elite, both in Anglo Saxon countries and the Netherlands, where the label middlebrow as such was not in use, but where the same phenomenon manifested itself in the interwar years. A new in-between culture developed, consisting of accessible, attractive yet serious novels and of all kinds of initiatives and institutions to reach the new, fairly educated reading public. Among these initiatives were journals, informative criticism, book series, lecture series and public libraries. It is only recently that these phenomena are studied and analyzed in the Netherlands to provide a more differentiated image of Dutch culture and literature of the interwar years. As in the UK, the 1930s were the heyday of culture debates and even 'culture wars' about what leading Dutch critics called the growing 'mediocrity' i.e. the effects of democratization and market forces in literature.

2 However, this does not mean that middlebrow did not exist prior to these explicit controversies. Middlebrow culture did not appear out of the blue. In fact, in the first decade of the 20th century a new type of novel was launched in the Netherlands which was both entertaining and instructive and in retrospect can be classified as a typical 'middlebrow novel'. The release of this novel was the joint effort of a publisher, Leo Simons, and a husband-and-wife writers' team, Carel Scharten and Margo SchartenAntink. Thus, they gave the impetus to the development of a tradition of literary 'midcult' in the Netherlands which came to full flower in the 20s and 30s. The new novel they 
introduced is not to be seen as merely a new genre, but rather as a product of new cultural practices which are at the heart of $20^{\text {th }}$ century middlebrow culture.

\section{The World Library of Leo Simons: home university for new readers}

3 In 1905 Leo Simons founded his publishing house 'World Library' (Wereldbibliotheek) with the intention 'to serve the education and culture of our people (in its broadest sense)'. ii Simons had a high opinion of his profession. He was a shrewd businessman - in fact, he introduced many commercial innovations in the book market - but above all he considered publishing to be what he called a nobile officium, a profession with a 'responsibility to civilization as a whole, to our literature, and to culture of all mankind. 'iii The connection Simons makes between literature and education/civilization shows immediately what is at the heart of his views. He regarded literature primarily from the point of view of its function to the reader. Titles of his numerous public lectures show this clearly: 'Why do we read books?' 'How do we read books best?' 'Books and private study (zelfstudie)' 'Books and the education of the self' and 'How can I advance in society?' According to Simons' conception, books are educational and contribute to the development of public knowledge. The key word is 'self-enrichment'; individual development will increase the general level of civilization in society. This belief was the basis of his life's work, the publishing house 'World Library'. The slogan of the World Library was the famous dictum of Thomas Carlyle: 'The greatest university of all is a collection of books', which became the motto of the main series of World Library, the 'Dutch Library', printed in each volume.

4 This concept of literature as an informal educational system in addition to the official training institutions was part of an international trend in the early $20^{\text {th }}$ century. In Germany as early as 1867 there existed the Reclams Universal-Bibliothek which disseminated cheap editions of classic books under the motto 'Bilding für Alle!' A year after Simons' initiative, in 1906, the English publisher Joseph Dent launched the Everyman's library, based on the same principle: high circulation, low prices, well designed covers and classic texts, attractive for 'every kind of reader'. In the USA, similar initiatives were taken. As several scholars of the American middlebrow have described, concepts of literature as an informal university for self-education arose in connection with the rise of the new middle classes. These new middle classes, situated between 'owners' and 'workers', were fairly well educated but without academic training. They were mainly trained for the new professions of the early $20^{\text {th }}$ century: administration, office, trade, teaching, journalism. For them, literature could serve as a means to further education and a way of obtaining social status. 'Use' and 'utility' are keywords used by Melanie Ho who refers to 'a middlebrow commitment to utilitarian, even pedagogical, reading. ${ }^{\text {iv }}$ Ho, Rubin and Radway mention numerous new initiatives and institutions that gave shape to these ideas: book clubs, series of 'Great Books', 'outline' volumes, literary sections in journals, public lectures. Through these channels the official literature was disseminated, but also a more accessible middlebrow literature was spread. ${ }^{\mathrm{v}}$

5 The publishing house of Leo Simons fits within this international context. His World Library was set up as an educational route for people without a university training. Its goal, the broad distribution of 'good books', was clearly different from other Dutch 
publishing houses in its emphasis on education and its offering of a pedagogical framework and pedagogical guidance, as Frank de Glas remarks in his study of the firm: 'By the early 1920s the WB [World Library] tried to align itself with other, noncommercial institutions for education and development.' ${ }^{\text {vi }}$ All Leo Simons' initiatives served his educational objectives. He offered the option of subscriptions to book series which provided a more sensible choice of books than readers could have made themselves. Furthermore, he published editions with introductions and annotations, books with overviews or introductions on specialized fields of learning and practical selfhelp books. All this was meant to open the eyes, to offer clarity, understanding and knowledge, and to broaden the horizon of the public, as Simons explained in an early volume of De Ploeg, journal of the World Library. ${ }^{\text {vii }}$ In 1925, he founded a 'World Library Organization' to reinforce the relations between the members because he thought that a community spirit would encourage development. With the same objective in mind, he tried to establish reading communities but that did not succeed. Yet he felt that an atmosphere of togetherness would foster the circulation of 'good books'. viii

6 At first, Simons had a special interest in reaching the working classes. Since the end of the $19^{\text {th }}$ century, there had been a series of initiatives to promote community development and social reform, in particular by making culture available to the working classes under the motto 'culture for the people' ('Kunst aan het volk'). Leo Simons was involved in these democratization projects from the beginning. After a while the difficulty of reaching these populations became more and more apparent. It was rather the more educated people who took keen advantage of the exhibitions, presentations and lectures on literature and art. Office workers, technicians, teachers, civil servants came flocking to the community centers and Toynbee Halls in the Dutch major cities of the early twentieth century. The same applied to the World Library. Simons soon came to realize rather than the working class or 'the masses', it was the more educated who were the World Library's main customers. In fact, the clientele at the World Library's tenth anniversary was described by Simons as 'the more educated with limited income: laborers, teachers, civil servants, office workers, small entrepreneurs, artists, journalists and, more and more, people in rural areas. ${ }^{{ }^{1} \mathrm{x}}$ After 1900, these lower middleclass people were a rapidly growing social group. They became the growing new reading public later indicated as 'the common reader'. This common reader, without specific literary competence but with a clear interest in literature and education, appeared in various European countries as a rising cultural category with an increasing impact on the book market.

7 Simons kept working at offering education to these groups and raising the general level of culture. From the beginning, he was warmly endorsed for his efforts in 'the book and the journal as a means to self-education for the Dutch people', as one newspaper put it in 1909. ${ }^{\mathrm{x}}$ In the World Library memorial book, published at its $25^{\text {th }}$ anniversary in 1930 , various representatives of educational institutions are cited, praising the publishing house as a 'university without state aid', 'a university in the home, a home library for the self-educating public, which gives Dutch culture a hitherto missing broad foundation. ${ }^{{ }^{x i}}$

\section{'New novels'}

8 Fiction was an important category in the World Library's backlist and even fiction was conceived of in educational terms. 'Good books' were to be provided that could enrich 
and improve the readers. Initially, Simons focused on reprinting Dutch classics such as works of the famous $17^{\text {th }}$ century poet Vondel, the much loved $18^{\text {th }}$ century women novelists Betje Wolff and Aagje Deken and the highly valued $19^{\text {th }}$ century author Multatuli, as well as international literary masterpieces (Goethe, Ibsen, Flaubert, Shaw, Wilde). Quite soon it turned out to be possible and financially attractive to start publishing new work by living Dutch and Flemish authors. This category of modern Dutch fiction was to develop into the major and most profitable segment of the World Library's backlist. ${ }^{\text {xii }}$

9 The decision to publish modern Dutch novels was partly based on economic motives. Committing living novelists to the publishing house for the long term could provide a sound basis for the firm. ${ }^{\text {xii }}$ But there were also idealistic considerations related to the Dutch literary context at the time. With regard to the state of Dutch literature, two things were worrying Simons. His first concern was the evolution of modern literature in the Netherlands. Since the 1880s, when the so-called 'Movement of 1880' (a group of young modernist authors) had come to the fore, there was a growing gap between modern literature and the reading public. Ever since the foundation of the World Library, Simons had expressed his concern about what he called the increasing alienation between our newer literature and our vast audience.' ${ }^{\text {xiv }}$ This feeling was shared by critics and authors who bewailed the fact that modern literature was distancing itself from the common reader. In the 20s and 30s, many protagonists repeated the complaint that Dutch literature since 1880 had turned into an 'art for art's sake' ('kunstenaarsliteratuur') unlikely to appeal to a wider public: 'our literature is not being read!'xv

On the other hand, and that was maybe an even more serious concern, there was a huge range of reading matter for popular entertainment, such as romances, detective-, murder- and crime stories, available at cheap prices at news-stands and railway stations and also sold door to door. It included series and novels such as the detective series Nick Carter, Buffalo Bill, Raffles, Lord Lister and Harrison sold per episode for 10 cents each, and all kinds of novels for adults and children: adventure, crime and romance, sold per chapter for prices between 1,5 and 10 cents each. ${ }^{\text {vi }}$ The circulation was huge and amounted to tens, even hundreds of thousands. This kind of reading was thought merely entertaining, even numbing and thus damaging to the least educated masses who were the target consumers. In 1910, a range of public institutions (especially associations of teachers and libraries) started a 'War on Titillating Readings' (Bestrijding der Prikkellectuur). In this movement, Leo Simons was the initiator and the driving force; he even tried to establish an 'Agency against the Production of Titillating Books' (but that did not happen after all).xvii In his report of the first meeting, Simons deals extensively with one specimen of the books in question: Laura, Victim of Crime and Swindle, to demonstrate how the 'hyper melodramatic characters, violent crime, supernatural coincidences' represent an artificial world which is a misrepresentation of reality, misleading and damaging the readers. The same applies to 'the glorification of the gentleman-thief Raffles', to Lord Lister and 'Harrison, the detective -spiritualist', which, he argues, offer false values, arousing and straining the nerves of the readers. Simons wrote that 'the enemy' manifested itself mainly as these two types, the novels and the series, which were all widely read. Of the 52 episodes of Laura more than 100.000 copies were sold and other examples even reached sales of 200.000. xviii These figures were far higher than the numbers the World Library editions ever reached. Clearly, in his condemnation of these popular serial products Simons was not only driven by idealistic 
concern for the mental health and development of the public, but also by a certain commercial envy. Commercially, these lowbrow products were extremely profitable, and Simons was highly interested in reaching such a vast pool of readers and making such high profits.

This whole complex of considerations: the worrying gap between modern Dutch literature and the reading public on the one hand and the alarming influence of cheap lowbrow productions on the other, as well as the commercial possibilities this latter category promised, set the background for Simons' new initiative in 1909: the start of a series of novels named 'New Novels'. His motives were both idealistic and commercial. What he wanted was to create a space for an alternative literature that was sound, positive and constructive, yet catchy enough to attract many readers. ${ }^{\text {xix }}$ Simons himself acted as the editor of the series. With a duration of nearly thirty years (1909-1938) and 113 volumes the 'New Novels' would grow to become one of the most longstanding and comprehensive series of the World Library.

\section{'Good books': social cognition avant la lettre}

12 For the 'New Novels', Leo Simons sought modern Dutch novels of good literary quality yet marketable to a vast public. Which kind of books did he have in mind? In several lectures, Simons explained his views on 'good books', which were instructive and also captivating. In this respect he had no strict preconceived opinion. He had no preference for 'community art' (gemeenschapskunst) or 'literature for the people'; he also valued 'writers for the happy few', under the motto of 'uplifting': 'because our task of civilization aims to elevate the many to the sensitivity of the few!'xx Similarly, he did not demand that novels contain a 'sound moral'. In his view, the instructive value of novels was related neither to the delivery of a moral message nor to the provision of textbook information. It was Simons' conviction that the usefulness of novels lay in the life lessons they offered the reader. Good books, he said on several occasions, 'teach us the depths of life and give us a foundation for our existence. ${ }^{\text {xxi }}$ Novelists are experts in human life and human beings, and teach their readers to view those from their perspective. Thus, the readers gain knowledge of human nature and love for other people; sympathy for the novel's characters is a remedy against selfishness and produces education and civilization. Novels can offer 'inner self-enrichment towards a higher form of life and a higher state of being.' xxii

13 Today, this understanding of the effects of fiction is classified under the heading 'social cognition', which means the ability to understand other people and oneself. In recent research into literature and psychology, these effects of fiction are attracting more and more attention. There is increasing evidence that literature enhances self-reflection, selfunderstanding, empathy and sensitivity. Through identification with the novel's characters, the reader gains a deeper understanding of the moral/ethical and emotional aspects of life. .xiii About a century ago, Simons reflected on the beneficial effects of reading fiction along the same lines. However, he was also concerned about the artistic form. He did not support the cult of aesthetic form preached by the earlier mentioned 'Movement of 1880', but he did value literary qualities such as 'pure depiction, the timbre of words, the construction of the sentence' which consciously or unconsciously affect the reader and shape their emotional response. ${ }^{\text {xiv }}$ With his 'New Novels', he wanted to 
provide the readers not only with a moral and social, but also with an artistic literary education.

\section{The Schartens: private authors of the World Library} could be committed to the World Library for the long term. The association he established with the husband-and-wife team Carel Scharten and Margo Scharten-Antink would be life long.

15 Carel Scharten and Margo Antink had each built their reputation separately, Carel Scharten with poems, essays and reviews in the well-respected journal De Gids and Margo Antink with highly praised novels Catherine (1899) and Sprotje (1905). After their marriage in 1902, they started their teamwork that would generate dozens of novels. They made a name for themselves as a beloved husband and wife team, a shared authorial reputation that would last their whole lives. In 1906, Simons had been able to buy Sprotje from a publisher colleague, a book that turned out to be a steady seller for several decades, and a solid basis for further cooperation was established. In 1908, in view of his plan for the 'New Novels', Simons consulted the writer-couple about the possibility of their first joint product, the novel A house full of people (Een huis vol menschen) being the first volume of the new series. The Schartens consented and the opening of the series in 1909 was a big success right from the start. ${ }^{\mathrm{xx}} A$ house full of people was marketed both separately and as part of a subscription. The first 4000 copies, of which 3200 were for subscribers, were soon sold out. In the end, 19 editions were published and 23.550 copies sold. These figures made the novel into one of the first Dutch bestsellers - a term, by the way, that was not yet used at the time as it was coined only in the 1920s.

Over the years, the Schartens remained major contributors to the 'New Novels'. They delivered several bestsellers such as Happiness hangs as a bunch of grapes (' $t$ Geluk hangt als een druiventros 1918; 28 editions, 44.000 copies sold) and the trilogy Francesco Campana. The latter was published from 1924 on and became the major bestseller of the interwar years; 107.000 copies were sold altogether, a huge number at a time when an average book had a circulation of a few thousand copies. By that time, the 'Schartennovel' had become a catchword, even a trademark in Dutch literature. The Schartens remained loyal to the World Library for decades. Nearly all of their joint novels, as many as 18 , were published there. Amongst the regular World Library writers, they were the most productive and successful; their names became inseparably linked to that of the firm. In many respects, this publisher and this authorial couple were a perfect match.

17 Carel Scharten's views on literature and society were fully in line with Simons' ideals of education and civilization. Although Carel Scharten had started his career as an advocate of the modernist 'Movement of 1880 ' - which was the normal thing to do for any ambitious young writer after 1880- he had chosen a different route quite soon, at the age of twenty. He discovered socialism and developed a new concept of art, which 'appeals' to the people, which is not only for the happy few, but 'can inspire a people to discover itself and become a coherent whole (unity). ${ }^{\text {xxvi }}$ It was his conviction that the novelist had a higher calling, not to change society or to bring material improvement to the masses, but to change their inner life, their emotional life. His mission statement, the mission of his novels was 'to uncover humanity to itself, to offer self-understanding.'xxvii With their novels, Carel Scharten and Margo Scharten-Antink explicitly aspired to increase the 
insight and level of understanding of the readers. It is our 'best thought, to try to understand people and to make them understand themselves, by reshaping and interpreting them in our books.' The novel will be 'one of the instruments to bring progress to humanity.'. ${ }^{x}$ viii This concept of the novel as an instrument for education and civilization was entirely in line with Simons' conception of 'good books'.

18 The reform the Schartens aspired to was not a matter of innovation in literary form. They were well aware that their novels were traditional in that respect. What was new was their idealistic, public oriented (and market oriented) approach which differed radically from the modernist project of 'arts for art's sake' that had become dominant at the time. In this respect too, they were in line with Simons: 'The [modern writers of the Eighties] don't care if they are understood because they reject "the public",-we have turned back to mankind.'xxix

\section{The middlebrow novel as a new literary practice}

19 In recent research, views and concepts such as those of Simons and Scharten have been labelled 'middlebrow'. These concepts of literature as an instrument of education for new readers fit in with international middlebrow trends as described by Rubin, Radway, Harker and Ho. That goes too for Simons' and Schartens emphasis on 'sameness', 'unity' and 'community' as core values in culture. It is especially true of their instrumental view on literature, the focus on 'use' and 'utility', on the 'self-development' of the new middle classes, literature as a self-help genre that could offer the readers self-reflection, reflection on life and understanding of social relationships. What Simons and Scharten promoted is what Radway has called 'a kind of social pedagogy', $x x x$ the idea that readers, via identification with the characters, could deepen their understanding of themselves and others and their place in society. Identification and empathy with the fictional characters and hence socialization and civilization was at stake in the 'New Novels' Simons and the Schartens initiated.

20 These 'New Novels' did not represent a new literary genre. Realistic novels with an educational intention were nothing new in themselves. This phenomenon was well known in the Netherlands from the widely read pedagogical novel of Betje Wolff and Aagje Deken, The History of Miss Sara Burgerhart (1782). In the nineteenth century it had been quite customary for literature to be used as an instrument for civilizing citizens. What was at stake was rather a new literary practice whose novelty lay in the different literary and social conditions of the early twentieth century.

21 As mentioned above, the literary field had undergone structural changes since the nineteenth century. First, the aforementioned group of new readers had increased. The moderately educated middle classes were expanding in numbers, and the common reader became a considerable category with its own cultural and social needs. Secondly, the modern novel, introduced by the Movement of 1880 , which by now had achieved the status of official 'high literature', did not at all respond to the needs and wishes of these readers. Faced with this new constellation, Simons and the Schartens developed new literary practices, aiming to establish a novel whose central point was the relationship with the public.

22 What were the possibilities in this area, that is, what were the existing models concerning the relation between novel and public? On this point, Dutch literature of the 
early twentieth century can be described in the terms Jonathan Franzen introduced when answering the question 'how fiction relates to its audience'. Franzen distinguishes between 'two wildly different models'. First there is the 'status model', which is about 'genius and art historical importance', about great works of art whose value exists independently of the reader's appreciation. In the opposing 'contract model' a novel 'represents a compact between the writer and the reader'. Here, the writer wants to communicate and to connect to his readers, and pleasure and connection are keywords. In addition, the contract model has points of reference to the commercial terms of production and consumption. ${ }^{\text {xxi }}$ These two models can arguably be mapped onto Bourdieu's distinction between the principles of 'restricted production' and 'large scale production', in the sense that the status model will dominate in the sub-field of restricted production while the contract model will determine the sub-field of large scale production. ${ }^{\text {xxxi }}$

23 Indeed, these were the dominant forms in early twentieth century Dutch literature. Simons and the Schartens were well aware of this, even if they used other terms. The status model was represented in modernist literature with its proclaimed indifference to the 'facile' pleasures of the general public. This was the so-called 'literature for art's sake' characterized in terms of autonomy in the sense that readers and market were rejected, which was exactly why Simons and the Schartens could not make use of this model. They admired this modern literature's quality and prestige, but they aspired to a social kind of novel that readers would appreciate. The contract model was evident in widely read novels by Dutch women authors such as Thérèse Hoven or Melati van Java or in the popular translated works of Marie Corelli and Hedwig Courths Mahler. It was also apparent in the many serial lowbrow products that Simons was fighting against, as mentioned above. This was mere easy entertainment without literary ambition and as such could offer no basis for the 'New Novels' that were meant to offer a social and literary education to the developing readers, although the circulation and profits of the lowbrow production were appealing.

24 There was, therefore, no suitable model available at the time. In fact, with the 'New Novels' Simons and the Schartens created a mix out of existing examples, a blending of aesthetics, education, entertainment and commerce. This mix was a typical middlebrow form in the sense that well known, longstanding models were transformed into this new phenomenon and adapted to the new social circumstances. The 'New Novels', firstly published in 1909, would become fashionable books, even bestsellers. As such, they were 'in between books' ('tusschen-dingen') between the elitist high literature and the disputed low brow, as Simons stated in 1909. xxxiii The above seems to indicate that Simons and the Schartens were deliberately constructing a new literary mode in approaching and affecting the audience, which can constitute an argument for Jaime Harker's thesis 'Middlebrow writing is created by design, not by default.' ${ }^{\text {'xxiv }}$ It also supports the argument of Beth Driscoll that Bourdieu's opposition between restricted production and large scale or market driven production is contestable, because such a dichotomy doesn't take account of the interrelations between literary and commercial practices which are typical for this in-between cultural formation. ${ }^{\mathrm{xxx}}$ 


\section{'New Novels' on the book market}

as well as readers. These ads show a remarkable evolution: increasingly, success and sale figures themselves became central to marketing strategy as can be seen in slogans such as 'A book that must be read and will be read!', 'A series which is a great Success!', and one year later, printed in large black letters: '6000 copies sold!', 'THIS WEEK AGAIN A NEW EDITION, $7^{\text {th }} 1000^{\text {' }}$. xxix This is the language of the bestseller in which figures of circulation and sales are crucial, based on the first bestseller principle that success generates success. In 1909, this kind of language and this approach were a novelty. This was the beginning of the dominant commercial strategy in the $20^{\text {th }}$ century book market.

\section{A house full of people. Response and impact}

It was precisely the immediate and exceptional success of A house full of people that was striking. In this one respect, reviewers regarded the novel as a novelty. It was 'an event [...] in the calm existence of today's literature', as one journalist put it in the pages of De Gids. The extent to which this first volume of the 'New Novels' became the hot topic of the day struck all reviewers. Frans Coenen mentioned 'the big success', 'the enormous popularity' of the novel. 'Nearly everyone will have read it by now', wrote the critic Gerard van Eckeren, and his colleague Herman Robbers asserted that 'almost every

Belphégor, 15-2 | 2017 
reader in the Netherlands will have enjoyed it or will enjoy it'. Yet another critic, Van Nouhuys, declared that 'This novel will certainly make its authors into celebrities'.

Explanations for the large public response were not sought in the novel's theme or form. As said before, in these respects the novel was merely traditional. Stories about an apartment block in Paris such as A house full of people, A story from life in Paris in the early years of this century were a well-known genre. The apartment block of the Schartens contained numerous well-established elements such as the romantic picture of the fallen woman, depicted as a victim and placed on a pedestal. In these respects, the book reminded reviewers of the famous novel of Henri Murger, Scènes de la vie bohême (1851).

Yet, the specific way the Schartens had revived the traditional Parisian apartment block could well explain the novel's success. Critics observed that the authors had created lovable characters who could easily win the readers' hearts, spark interest and sympathy and 'who one is glad to meet again'. In this house the reader could feel at home, 'We felt at home in the house where the Schartens showed us around', a critic wrote and another one remarked 'This entertaining book offers compensation for the many sad themes that nowadays dominate the novel in our low countries.' Apparently, this critic saw a positive difference with modern literature that since late nineteenth century was influenced by a gloomy naturalism.

31 Nowadays, the features reviewers referred to are regarded as the typical traits that make middlebrow novels attractive to their readers, that is, the 'audience-friendly' narrative, 'accessibilty', 'likeability', empathy with 'loveable characters', an author who guides readers through the narrative world and optimism as compared to the pessimism of modernist literature. With these elements middlebrow novels fulfilled their educational task, offered life lessons and disseminated social values while at the same time providing a pleasurable reading experience. Apparently, A house full of people possessed these features to a large extent and its social message was also clear. Simons had amply explained the novel's educational social aspects in The Plough and critics had adopted these views in their reviews.

The social merit, Simons had explained, lay in the portrait of people from all walks of bourgeois life, rich and poor, simple and dignified, living under one roof together and thus showing an instructive mini-society. A house full of people is about the everyday life of the 32 inhabitants of the rooms and apartments in a Parisian boarding house, supervised by a concierge couple that keeps a close eye on the moral standards of the residents. Such a mini-society, a 'pile of human life' offers great opportunities for social and moral lessons. In fact, the house represents a variant of the reader's own life setting, and provides models of the social world and one's place within it, thus enabling reflection on one's own existence.

This is what constitutes its social cognitive function. In a recent study, Jean Marie Schaeffer considers social cognition as the effect of the so-called 'fictional modelization' which takes place when readers become immersed in the world of fiction and identify with the characters. ${ }^{\mathrm{xl}} A$ house full of people is tailored to this role-taking and the narrative empathy involved. Being in this house and living the lives of the various characters, the reader receives a range of lessons about possible life styles, forms of society, interiors, tastes, art, customs and habits, and a series of moral lessons as well. The main lesson of life is that one should not trust prejudices. Petty, moralistic ideas on propriety such as those of the concierge couple who represent the reputable house, are dismantled. For 
example, Jozette, the 'fallen girl', the artist's mistress, disapproved of by the respectable house, turns out to be a positive ideal of femininity despite her 'indecent' behavior. Anyone who identifies with her role and gains access to her thoughts obtains a new understanding of her true nature and will cease to condemn her.

The novel does not conclude with a happy ending. Jozette disappears without trace and other characters face an uncertain future. Yet, there is no disappointment or disillusionment as in most modernist novels but rather what middlebrow studies describe as an 'optimism of the will'xli , which involves no unrealistically positive narrative turn, but rather implies a belief that individuals faced with adversity have the ability to search for solutions and make up their own minds. Middlebrow novels create a world in which individuals have agency and can exert influence. ${ }^{\text {llii }}$ Characters in A house full of people are not the passive victims of harsh reality, fate or their predisposition. Through trial and error they deal with the problems they face. Thus, the novel offers the reader a place for introspection and reflection on human conduct and social relations. And it is a pleasant place too: readers pass agreeable hours in this welcoming house. It is this combination of life lessons, reading pleasure and commercialism that made the middlebrow novel a new phenomenon in early twentieth century Dutch literature.

This first volume of the 'New Novels' is an early example of the way Dutch authors and publishers responded to the assumed needs and wishes of the new readership after 1900 by publishing serious though entertaining novels tailored to the new readers' standards. The 'New Novels' lasted until 1938. In general, they were valued in the way they were intended, as good, serious and solid Dutch novels for the common reader. As such, they were a part of the growing literary 'midcult' in the Netherlands which in the 1930s encountered fierce opposition from the elitist critics who dominated the literary scene at that time. In the intervening decades, the series had fulfilled an important function. Simons' 'New Novels' series helped to democratize access to literature and had a clear impact on the reading of the Dutch public. It disseminated a new 'readerly' poetics and a new view of literary value. Moreover, it encouraged large numbers of readers to read the same books, many of which became the talking points of the day. Thus, the 'New Novels' stimulated reading as a communal activity which is seen as a key middlebrow phenomenon. ${ }^{\text {xlii }}$ Part of these new practices were the modern commercial strategies which accompanied the introduction of the New Novels. With the above in mind, we can conclude that Simons' enterprise indeed played a significant role in the development of Dutch middlebrow and in the establishment of the modern book market.

\section{BIBLIOGRAPHY}

Bourdieu, Pierre. 'The market of Symbolic Goods.' In: The Field of Cultural Production, Cambridge UK: Polity Press 1993, 112-141.

Driscoll, Beth. The New Literary Middlebrow. Tastemakers and Readers in the Twenty-First Century. Palgrave MacMillan, 2014. 
Franzen, Jonathan. 'Mister Difficult'. In: How to be alone. London : HarperPerennial 2004, 239-241. Gedenkboek der Wereldbibliotheek 1905-1915. Amsterdam : Maatschappij voor Goede en Goedkoope lectuur, 1915.

Gedenkboek van het 25-jarig bestaan der Wereldbibliotheek. Amsterdam : Maatschappij voor Goede en Goedkoope lectuur, 1930.

Glas, Frank de. Nieuwe lezers voor het goede boek. Amsterdam: Wereldbibliotheek, 1989.

Hakemulder, J. The Moral Laboratory. Experiments Examining the Effects of Reading Literature on Social Perception and Moral Self-Concept. Amsterdam: John Benjamins B.V., 2000.

Harker, Jaime. America the Middlebrow: Women's novels, Progressivism and Middlebrow Authorship between the Wars. Amhurst: University of Massachusetts Press, 2007.

Ho, Melanie. Useful fiction: Why Universities Need Middlebrow Literature. Ann Arbor: ProQuest, 2008.

Humble, Nicola. The Feminine Middlebrow Novel 1920s to 1950s: Class, Domesticity, and Bohemianism. Oxford: Oxford University Press, 2004.

Jong, A.M. ‘Ter inleiding'. In : Nu. Algemeen maandblad 1 (1927-1928), 1, 9.

Oliveira, E. d'. ‘Carel Scharten' In : De jongere generatie. Vervolg op 'De mannen van ‘80'. Amsterdam : Maatschappij voor Goede en Goedkoope lectuur, 1914, 158-176.

Radway, Janice. A Feeling for Books. The Book-of-the-Month Club, Literary taste, and Middle-Class Desire. Chapel Hill \& London: The University of North Carolina Press, 1997.

Rubin, Joan Shelley. The Making of Middlebrow Culture. Chapel Hill \& London: The University of North Carolina Press, 1992.

Schaeffer, Jean Marie. Why Fiction? Lincoln: University of Nebraska Press, 2010.

Scharten-Antink, C. en M. Een huis vol menschen. Een verhaal uit het Parijsche leven van de eerste jaren dezer eeuw. Amsterdam/Antwerpen : Wereldbibliotheek N.V., 1909.

Simons, Leo. 'Hoe "Een huis vol menschen" ontstaan is ?' In : De Ploeg. Geillustreerd maandblad der Wereldbibliotheek. 1 (1908-1909), 81-88.

Simons, Leo. '"Een Huis vol Menschen" een..."verderfelijk" boek !' In : De Ploeg. Geillustreerd maandblad der Wereldbibliotheek. 1 (1908-1909), 142-144.

Simons, Leo. 'Over Boeken-Schrijvers-Lezers. Een lezing.' In : De Ploeg. Geillustreerd maandblad der Wereldbibliotheek. 1 (1908-1909), 147-159 .

S.,L. [Leo Simons], 'Kunst aan het volk'. In : De Ploeg. Geillustreerd maandblad der Wereldbibliotheek. 2 (1909-1910), 126.

S. L., [Leo Simons], 'Bestrijding der Prikkellectuur'. In : De Ploeg. Geillustreerd maandblad der Wereldbibliotheek. 3 (1910-1911), 232-247.

Simons, L. 'Het goedkoope boek'. In : Gedenkboek der Wereldbibliotheek 1905-1915, Amsterdam : Maatschappij voor Goede en Goedkoope Lectuur, 1915.

Simons, Leo. Tot afscheid (Boeken en hun beteekenis). Amsterdam: Wereldbibliotheek 1930.

Vermeule, Blakey. Why Do We Care About Literary Characters? Baltimore: The John Hopkins University Press, 2009. 


\section{ENDNOTES}

i. A partially different version of this article appeared as 'Literaire levenslessen. De eerste Schartenroman als model van een nieuwe middlebrowliteratuur' in Nederlandse Letterkunde vol 19 (2014), 3, 327-349.

ii. 'de ontwikkeling en cultuur van ons volk (dit in den ruimsten zin) te dienen'. Leo Simons, Tot afscheid (Boeken en hun beteekenis). Amsterdam: Wereldbibliotheek 1930, 21.

iii. 'verantwoordelijkheid jegens heel onze volksbeschaving, onze literatuur; jegens heel de menschheids-cultuur.' Leo Simons, 'Over Boeken-Schrijvers-Lezers. Een lezing.' In: De Ploeg 1 (1908-1909), 147-159 en 161-169, 168. (ook in: Tot afscheid (Boeken en hun beteekenis). Amsterdam: Wereldbibliotheek 1930, 51.)

iv. Melanie Ho, Useful fiction: Why Universities Need Middlebrow Literature. Ann Arbor: ProQuest, $2008,16$.

v. Joan Shelley Rubin, The Making of Middlebrow Culture. Chapel Hill \& London: The University of North Carolina Press 1992. Janice Radway, A Feeling for Books. The Book-of-the-Month Club, Literary taste, and Middle-Class Desire. Chapel Hill \& London: The University of North Carolina Press 1997.

vi. Frank de Glas, Nieuwe lezers voor het goede boek. Amsterdam: Wereldbibliotheek, 1989, 111.

vii. L.S. [Leo Simons], 'Kunst aan het volk'. In: De Ploeg, Geillustreerd maandblad der Wereldbibliotheek, 2 (1909-1910), 126.

viii. Frank de Glas, Nieuwe lezers voor het goede boek. Amsterdam: Wereldbibliotheek, 1989, 108.

ix. L. Simons, 'Het goedkoope boek'. In: Gedenkboek der Wereldbibliotheek 1905-1915, Amsterdam: Maatschappij voor Goede en Goedkoope Lectuur, 1915, 54.

x. 'Omdat we het streven van den heer Simons: het boek en het tijdschrift als middel tot zelfopvoeding van het geheele Nederlandsche volk, zoo van harte toejuichen.' (response from Het Vaderland, printed in De Ploeg, Geillustreerd maandblad der Wereld-bibliotheek, jg 1 (1908-1909), 79.

xi. Gedenkboek van het 25-jarig bestaan der Wereldbibliotheek. Amsterdam: Maatschappij voor Goede en Goedkoope lectuur, 1930, 69 and 57.

xii. Frank de Glas, Nieuwe lezers voor het goede boek. Amsterdam: Wereldbibliotheek, 1989, 169.

xiii. Ibidem, 79.

xiv. Gedenkboek van het 25-jarig bestaan der Wereldbibliotheek. Amsterdam: Maatschappij voor Goede en Goedkoope lectuur, 1930, 24.

xv. A.M. de Jong, 'Ter inleiding'. In: Nu. Algemeen maandblad 1 (1927-1928), 1, 9.

xvi. The value of 10 cts in 1910 is about one Euro in 2015.

xvii. L.S. [Leo Simons], 'Bestrijding der Prikkellectuur'. In: De Ploeg. Geillustreerd maandblad der Wereldbibliotheek. 3 (1910-1911), 232-247, 247.

xviii. L.S. [Leo Simons], 'Bestrijding der Prikkellectuur'. In: De Ploeg. Geillustreerd maandblad der Wereldbibliotheek. 3 (1910-1911), 232-247, 238.

xix. L.S. [Leo Simons], 'Bestrijding der Prikkellectuur'. In: De Ploeg. Geillustreerd maandblad der Wereldbibliotheek. 3 (1910-1911), 232-247, 240.

xx. L. Simons, Tot afscheid (Boeken en hun beteekenis). Amsterdam: Wereldbibliotheek 1930, 40.

xxi. Ibidem, 44.

xxii. 'De zelfverrijking, de innerlijke; tot een hoogere levensorde en een hoogere menschenstaat'. Ibidem, 69.

xxiii. J. Hakemulder, The Moral Laboratory. Experiments Examining the Effects of Reading Literature on Social Perception and Moral Self-Concept. Amsterdam: John Benjamins B.V., 2000.

Blakey Vermeule, Why Do We Care About Literary Characters? Baltimore: The John Hopkins University Press, 2009.

xxiv. Gedenkboek (1930), 24-25. 
xxv. C. en M. Scharten-Antink, Een huis vol menschen. Een verhaal uit het Parijsche leven van de eerste jaren dezer eeuw. Amsterdam/Antwerpen: Wereldbibliotheek N.V. 1909.

xxvi. 'die een volk bezielen [kan], zichzelf te vinden en een eenheid te worden'. E, d'Oliveira, 'Carel Scharten' In: De jongere generatie. Vervolg op 'De mannen van '80'. Amsterdam: Maatschappij voor Goede en Goedkoope lectuur, 1914, 182.

xxvii. 'de menschheid aan zichzelve te onthullen, zichzelve te doen verstaan.' Ibidem, 184.

xxviii. 'het is 'ons beider beste gedachte, te pogen [...] de menschen [...] te begrijpen, en te dóen begrijpen, door hen, innerlijk verklaard, te laten herleven in onze boeken'. De roman zal 'éen der instrumenten' zijn om 'de menschheid [...] vooruit te brengen.' Ibidem, 184.

xxix. 'De Nieuwe Gidsers gaven er niet om, of zij al dan niet begrepen werden, zij hadden lak aan "het publiek",-wij zijn tot de menschheid weergekeerd'. Ibidem, 188.

xxx. Janice Radway , A Feeling for Books. The Book-of-the-Month Club, Literary taste, and Middle-Class Desire. Chapel Hill \& London: The University of North Carolina Press 1997, 15.

xxxi. Jonathan Franzen, 'Mister Difficult'. In: How to be alone. London: HarperPerennial 2004, 239-241.

xxxii. Pierre Bourdieu, 'The market of Symbolic Goods.' In: The Field of Cultural Production, Cambridge UK: Polity Press 1993, 112-141.

xxxiii. L. Simons, 'Over boeken-Schrijvers-Lezers (een lezing) 'In: De Ploeg 1 (1908-1909), 150.

xxxiv. Jaime Harker, America the Middlebrow: Women's novels, Progressivism and Middlebrow Authorship between the Wars. Amhurst: University of Massachusetts Press, 2007, 18.

xxxv. Beth Driscoll, The New Literary Middlebrow. Tastemakers and Readers in the Twenty-First Century , Palgrave MacMillan, 2014, 13.

xxxvi. "geabonneerd zijn op onze WERELD-BIBLIOTHEEK is deel hebben aan de Cultuur van vroeger, heden en toekomst"

xxxvii. Leo Simons, 'Hoe “Een huis vol menschen” ontstaan is?' In: De Ploeg 1 (1908-1909), 81-88.

xxxviii. Leo Simons, "”en Huis vol Menschen" een..."verderfelijk" boek!' In: De Ploeg 1 (1908-1909), 142-144.

xxxix. Adverstisements in Algemeen Handelsblad 5-11-1908, 14-2-1909, 9-1-1910, 6-2-1910.

xl. Jean-Marie Schaeffer, Why Fiction? Lincoln: University of Nebraska Press 2010, 173-204.

xli. Melanie Ho, Useful fiction: Why Universities Need Middlebrow Literature. Ann Arbor: ProQuest, 2008, 28.

xlii. Melanie Ho, Useful fiction: Why Universities Need Middlebrow Literature. Ann Arbor: ProQuest, 2008, 27-30.

xliii. Nicola Humble, The Feminine Middlebrow Novel 1920s to 1950s: Class, Domesticity, and Bohemianism. Oxford: 2004, 46.

\section{ABSTRACTS}

Presenting the case of the introduction of a series of 'New Novels' in 1909, this article analyzes the early beginning of literary midcult in the Netherlands. The 'New Novels' were initiated by the Dutch publisher Leo Simons who in 1905 founded 'the World Library', a publishing house aimed at offering education to the increasing readership in the early twentieth century. Simons asked the Dutch husband-and-wife writers team Carel and Margo Scharten-Antink to write the first volume of the 'New Novels', and together they introduced the Netherlands to the middlebrow novel, which should not be seen as merely a new genre, but as a product of new cultural practices. The major goal of the middlebrow novel was, by way of 'fictional modelization', to provide the readers with life-lessons and role models. ${ }^{i}$ 
INDEX

Mots-clés: middlebrow, middleclass, utility, life lessons, book market

\section{AUTHOR}

\section{ERICA VAN BOVEN}

Open University of the Netherlands

Erica van Boven is professor of literature at the Open University (The Netherlands). Her research focuses on Dutch literature and literary criticism of the interwar period with special interest for middlebrow and gender. Her most recent book is Bestsellers in Nederland 1900-2015 (Garant 2015). She supervised the research project Dutch Middlebrow Literature 1930-1940: Production, Distribution, Reception (2013-2017), funded by the Netherlands Organisation for Scientific Research (NWO), on which six researchers from Dutch universities worked together studying the various forms in which middlebrow manifested itself in the Netherlands in the interwar years. 